\title{
Pulmonary Thromboembolism Associated with Human Chorionic Gonadotropin Misuse: A Case Report
}

\author{
Human Koryonik Gonadotropin Yanlış Kullanımı ile ilişsili Pulmoner \\ Tromboembolizm: Olgu Sunumu
}

Hülya Dirol' , Ayşe Ödemiş² ${ }^{2}$ Tülay Özdemir'

\begin{abstract}
Although many years have passed since the firs speculation that Human chorionic gonadotropin (hCG) could be effective in obesity treatment, its efficacy in this regard has yet to be proven. Unfortunately, we still come encounter hCG misuse, complicated with pulmonary thromboembolism. A 54-yearold female patient with no prior medical history presented to the outpatient clinic with pleuritic chest pain, but no other respiratory symptoms. Two months earlier, she had applied to a nutrition center to lose weight and had been started on a $125 \mathrm{IU} /$ day subcutaneous hCG injection and a $500 \mathrm{kcal} /$ day diet. After the injections, she experienced such complaints as flushing, breast bulging and minor vaginal bleeding, despite having passed menopause. Her vital signs and all physical examinations were normal. D-dimer $(610 \mathrm{ng} / \mathrm{dL})$ was slightly elevated. Mismatched subsegmental defects were determined in a ventilation/perfusion scintigraphy. She ceased the hCG injections immediately, and anticoagulant treatment was started, continuing for 3 months, although recovery has been uneventful to date. Literature contains one case in which ischemic stroke and one case in which pulmonary thromboembolism developed during hCG misuse for weight loss. Although it has yet to be proven, similar case reports increase the suspicion that such events are somehow related with hCG. More attention should be paid to this point when encountering such cases, and urgent legal regulations regarding to the misuse of hCG as part of a diet program should be prepared.
\end{abstract}

Key words: Pulmonary thromboembolism, human chorionic gonadotropin (hCG), obesity.

\section{Özet}

Insan koryonik gonadotropin (hCG)' in obezite tedavisinde etkili olduğuna dair ilk spekülasyonların üzerinden uzun yıllar geçmiş olmasına rağmen etkinliği kanıtlanamamışır. Ne yazık ki, pulmoner tromboembolizm ile komplike olan hCG kötüye kullanımı ile halen karşılaşmaktayız. Öncesinde bilinen bir hastalığı olmayan 54 yaşındaki kadın hasta plöritik göğüs ağrısı ile polikliniğe başvurdu. Başka solunumsal semptomu yoktu. İki ay önce kilo vermek için bir beslenme merkezine başvurmuş ve $500 \mathrm{kcal} /$ gün diyetle 125 IU / gün subkutan hCG enjeksiyonuna başlamışı. Hasta menopozda olmasına rağmen enjeksiyonlardan sonra yüzde kızarıklık, memede şişkinlik, minör vajinal kanama gibi şikayetleri gelişmişti. Vital bulguları ve fizik muayenesi normaldi. Ddimer (610 ng / dL) değeri biraz yüksek saptandı. Ventilasyon / perfüzyon sintigrafisinde mismatch subsegmental defektler görüldü. hCG enjeksiyonları hemen durduruldu. Antikoagülan tedavi başlandı. Tedaviye 3 ay devam edildi ve şimdiye kadar sorun yaşanmadı. Kilo kaybı için hCG yanlış kullanımı sırasında gelişen bir iskemik inme ve bir pulmoner tromboembolizm olgusu bildirilmiştir. Henüz kesin olmasa da benzer olgu raporları bu tür olayların bir şekilde hCG ile ilişkili olduğu şüphesini uyandırmaktadır. Mevcut olgularla bu noktaya daha fazla dikkat çekilmeli ve acilen hCG'nin diyet programı olarak kötüye kullanılmasıyla ilgili yasal düzenleme hazılanmalıdır.

Anahtar Sözcükler: Pulmoner tromboembolizm, insan koryonik gonadotropin (hCG), obezite.
'Department of Chest Diseases, Akdeniz University, Antalya, Turkey

${ }^{2}$ Department of Chest Diseases, Artvin State Hospital, Artvin, Turkey
'Akdeniz Üniversitesi Tıp Fakültesi, Göğüs Hastalıkları Ana-

bilim Dalı, Antalya

${ }^{2}$ Artvin Devlet Hastanesi, Göğüs Hastalıkları Kliniği, Artvin

Submitted (Başvuru tarihi): 06.02.2021 Accepted (Kabul tarihi): 15.03.2021

Correspondence (iletişim): Hülya Dirol, Department of Chest Diseases, Akdeniz University, Antalya, Turkey e-mail: hulyadirol@akdeniz.edu.tr 
Human chorionic gonadotropin ( $\mathrm{hCG}$ ) is a hormone that is usually used for ovulation or spermatogenesis induction, but has been used for reasons other than reproductive problems in recent years, having been used by the obese to lose weight or by athletes to improve performance $(1,2)$. Although it has been a long time since it was claimed hCG induced weight loss by increasing the fat metabolism, the effectiveness of hCG in the treatment of obesity has not yet been proven. There have been reports of cases experiencing thromboembolism during obesity treatment with hCG $(3,4)$. Even if the cause and effect relationship between hCG diet and thromboembolism is not certain, similar case reports raise suspicions. Here, we revisit this issue once again, reporting on a patient who developed a pulmonary thromboembolism (PTE) during hCG usage for weight loss, in order to contribute scientifically to the enactment of regulations and laws.

\section{CASE}

A 54-year-old female patient presented to our out-patient clinic with left-sided pleuritic chest pain for two days, and with no other respiratory symptoms. She was an active smoker, with a 15 pack-year smoking history. Her medical history was unremarkable. She had undergone regular routine health checks and had no comorbidity. She denied occupational-environmental exposure, pet at home or recent travel. She did not have a sedentary lifestyle. Two months earlier, she had applied to a nutrition center to lose weight and had been started on a 125 IU/day subcutaneous hCG injection with a $500 \mathrm{kcal} /$ day diet. After the injections, she developed such complaints as flushing, breast bulging and minor vaginal bleeding, despite having passed menopause.

Her vital signs were normal, and there was no remarkable pathological finding other than obesity upon a physical examination. Her d-dimer $(610 \mathrm{ng} / \mathrm{dL})$ was slightly elevated and the other blood tests, including complete blood count, liver and renal functions and $\mathrm{C}$-reactive protein, were normal. A right hilar fullness was detected on a posterior-anterior (PA) chest $\mathrm{X}$-ray (Figure 1).

A chest $C T$ angiography revealed no filling defect in the lobar or segmental branches of the pulmonary artery, although the diameter of the main pulmonary artery was minimally increased $(35 \mathrm{~mm}$ ) (Figure 2).

No deep venous thrombus was identified on bilateral lower extremity Doppler ultrasonography. Mismatched subsegmental perfusion/ ventilation defects were determined in the lower lobe superior segment and postero- basal segment of the left lung in the lung perfusion/ventilation scintigraphy (Figure 3).

She ceased the hCG injections immediately, and anticoagulant treatment was started, continuing for 3 months. All hereditary thrombophilia markers such as protein C, protein S, anti-thrombin III levels, Factor 5 Leiden and prothrombin 20210A, were normal.

\section{DISCUSSION}

The hCG hormone is produced by the trophoblasts in the early stages of pregnancy, and so is commonly used for the pregnancy determination. It reaches its highest levels in the 8th-10th weeks, $(100,000 \mathrm{IU} / \mathrm{ml})$, and decreases to $10,000-20,000 \mathrm{IU} / \mathrm{ml}$ after the 18th week, where it stays until partum. hCG plays a role in the in the synthesis of progesterone, estrogen and in the system of reninangiotensin. During pregnancy, there is an increase in estrogen synthesis, factor 2, 7, 9 and 10 levels, and a decrease in anti-thrombin III, activated protein C resistance and protein $\mathrm{S}$ levels. All of these physiological changes result in the incidence of PTE being higher in this period (5).

Similar changes occur in cases of hCG use, being a drug for the treatment of infertility. Ovarian hyperstimulation syndrome (OHSS) is a classical and catastrophic complication of hCG that is used for the ovulation induction. The risk of PTE is elevated in patients with OHSS. The exact mechanism of thrombosis is not known in OHSS, although a combination of increased thrombosis tenden$c y$, hypovolemia and hemoconcentration, may play a role in the coincidence of PTE with OHSS (6-8). PTE can occur not only in female patients, but also during the treatment of sub fertile male patients with hCG (9).

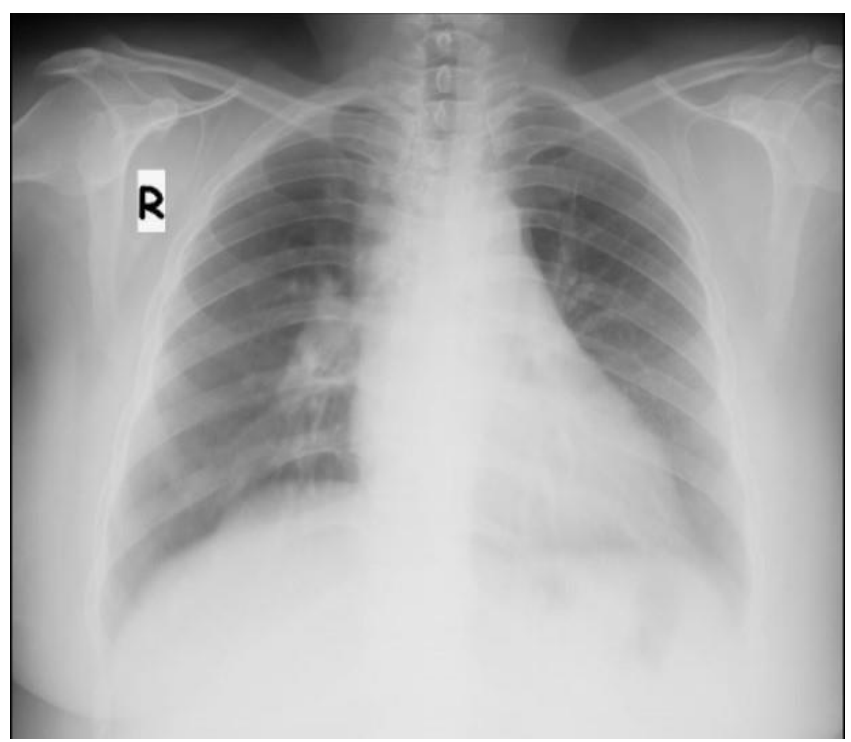

Figure 1: Right hilar fullness was detected on chest radiography 


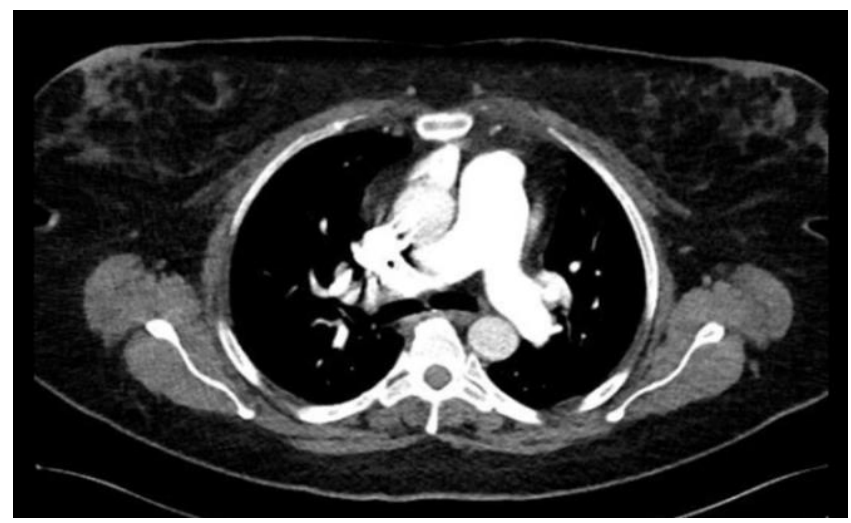

Figure 2: In a chest CT angiography, the diameter of the main pulmonary artery was minimally increased $(35 \mathrm{~mm})$

Beside the prescription of hCG as a drug for ovulation or spermatogenesis induction, it is nowadays sold under the counter for weight loss or for increasing the performance of athletes $(1,2)$. It was around 60 years ago that Dr. Simeons suggested hCG could be used for the treatment of the obesity, referring to a protocol including daily lowdose hCG injections and a very low in calorie diet for 6 weeks (10). Many studies have since been carried out investigating the effect of hCG on weight loss (11-14), although a meta-analysis of these studies revealed no scientific evidence of the effectivity of hCG for the treatment of obesity $(1,2)$. In 2009, the American Society of Bariatric Physicians declared that they did not recommend Simeons' protocol, but in spite of the scientific data, hCG still maintains its popularity.
Similar to our patient, there have been case reports describing pulmonary thromboembolism and ischemic stroke following hCG misuse for weight loss $(3,4)$ (The doses of hCG used for weight loss are generally 150-200 IU/day. Our patient was on $125 \mathrm{IU} /$ day subcutaneously). Although the hCG dose is higher in infertility treatment, such small amounts may be enough for the development of thromboembolism. Furthermore, as the half-life of hCG is 29-36 hours, before the terminal elimination has ended, the next dose is administered, and so the amount in circulation may be more than the daily dose. $\mathrm{hCG}$ in amounts between 500-4000 IU, can cause such side effects as headache, fatigue, irritability, depression and aggressive behavior, and the presence of these side effects in our patient supported the suggestion that the dose in circulation may be more than daily usage. Even the $200 \mathrm{IU} /$ day hCG dose used for infertility is enough to create some physiological responses (15), and so a daily dose of 125 IU hCG may not be such a low amount, and may also lead to side effects. In the case described by Nancy et al.(3), bilateral PTE developed after the administration of hCG in 20 drops, twice a day for 2 weeks, while another patient suffered ischemic stroke after using hCG 100 IU/day for 21 days (4).

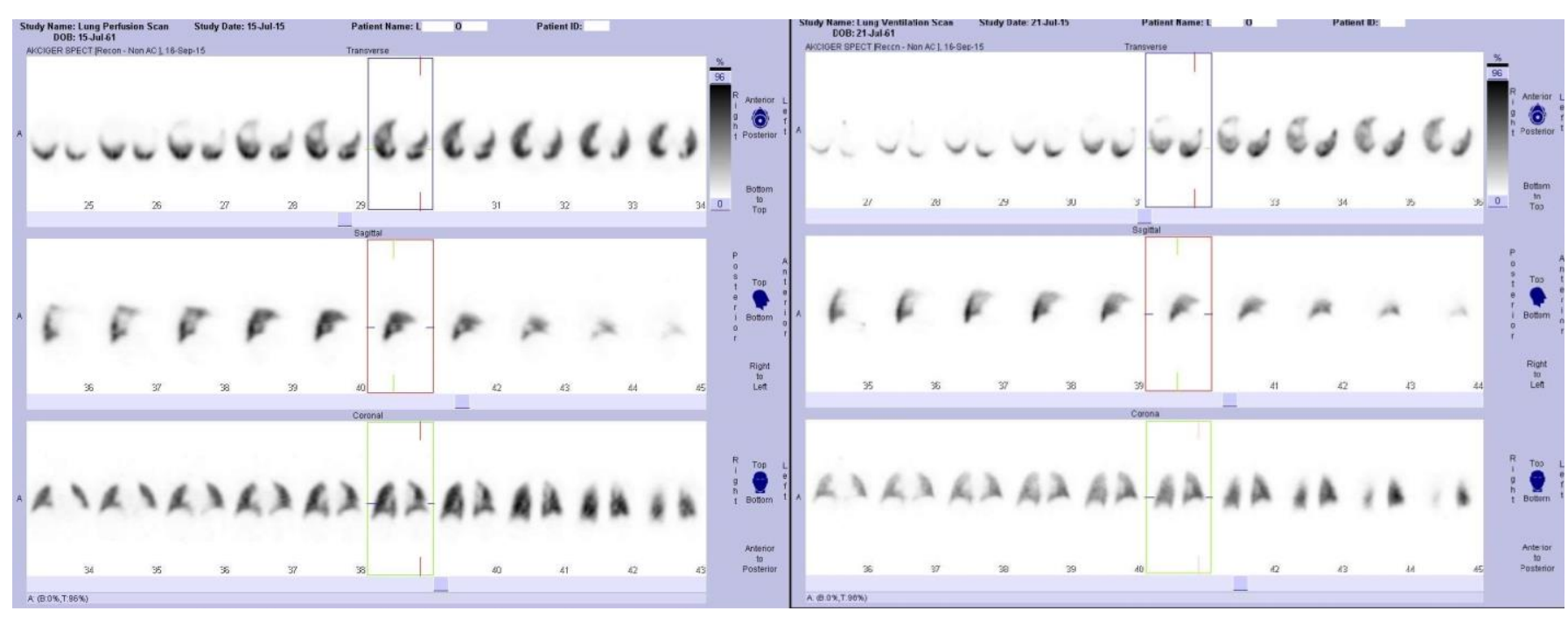

Figure 3: Mismatched subsegmental perfusion ventilation defects were determined in the lower lobe superior segment and posterobasal segment of the left lung in a lung perfusion ventilation scintigraphy 
No provoking factor other than hCG was present in our patient. We concluded that the hot flushes, breast swelling and vaginal bleeding were side effects other than PTE. In our case, as on the grounds of Nancy et al (3), the Naranjo probability scale suggested that hCG was the probable cause of all the side effects. The total hCG dose, which was more than the dose used for ovulation induction, was probably enough for the development of such physiological changes and even PTE. Somehow, hCG used for weight loss played a role in the development of PTE. The administration of hCG without obtaining informed consent is not ethical and should be banned. We hope reports such as these will be contribute to the enactment of laws related to hCG misuse.

\section{CONFLICTS OF INTEREST}

None declared.

\section{AUTHOR CONTRIBUTIONS}

Concept - H.D., A.Ö., T.Ö.; Planning and Design - H.D., A.Ö., T.Ö.; Supervision - H.D., A.Ö., T.Ö.; Funding H.D., A.Ö., T.Ö.; Materials - H.D., A.Ö., T.Ö.; Data Collection and/or Processing - H.D., A.Ö.; Analysis and/or Interpretation - H.D., T.Ö.; Literature Review H.D.; Writing - H.D.; Critical Review - H.D., A.Ö., T.Ö.

\section{YAZAR KATKILARI}

Fikir - H.D., A.Ö., T.Ö.; Tasarım ve Dizayn - H.D., A.Ö., T.Ö.; Denetleme - H.D., A.Ö., T.Ö.; Kaynaklar - H.D., A.Ö., T.Ö.; Malzemeler - H.D., A.Ö., T.Ö.; Veri Toplama ve/veya İşleme - H.D., A.Ö.; Analiz ve/veya Yorum H.D., T.Ö.; Literatür Taraması - H.D.; Yazıyı Yazan - H.D.; Eleştirel İnceleme - H.D., A.Ö., T.Ö.

\section{REFERENCES}

1. Lijesen GK, Theeuwen I, Assendelft WJ, Van Der Wal G. The effect of human chorionic gonadotropin (HCG) in the treatment of obesity by means of the Simeons therapy: a criteria-based meta-analysis. Br J Clin Pharmacol 1995; 40:237-43. [CrossRef]

2. Stenman UH, Hotakainen K, Alfthan H. Gonadotropins in doping: pharmacological basis and detection of illicit use. Br J Pharmacol 2008; 154:569-83. [CrossRef]

3. Goodbar NH, Foushee JA, Eagerton DH, Haynes KB, Johnson AA. Effect of the human chorionic gonadotropin diet on patient outcomes. Ann Pharmacother 2013; 47:e23. [CrossRef]
4. Pektezel MY, Bas DF, Topcuoglu MA, Arsava EM. Paradoxical consequence of human chorionic gonadotropin misuse. J Stroke Cerebrovasc Dis 2015; 24: e17-9. [CrossRef]

5. Gray G, Miles C, Wilson N, Jenks R, Cox M, Johnson AJ. The contrasting physiological and subjective effects of chewing gum on social stress. Appetite 2012; 58:554-8. [CrossRef]

6. Aurousseau MH, Samama MM, Belhassen A, Herve F, Hugues JN. Risk of thromboembolism in relation to an in-vitro fertilization programme: three case reports. Hum Reprod 1995; 10:94-7. [CrossRef]

7. Hocke C, Guyon F, Dulucq MC, Grenier N, Papaxanthos A, Leng JJ. Thromboembolism and ovarian hyperstimulation. J Gynecol Obstet Biol Reprod (Paris) 1995; 24:691-6.

8. Yoshii F, Ooki N, Shinohara Y, Uehara K, Mochimaru F. Multiple cerebral infarctions associated with ovarian hyperstimulation syndrome. Neurology 1999; 53:225-7. [CrossRef]

9. Dhabuwala CB, Kumar A, Pierce JM. Pulmonary embolism complicating human chorionic gonadotropin treatment in a patient with type IV hyperlipoproteinemia. Andrologia 1987; 19:66-8. [CrossRef]

10. Simeons AT. The action of chorionic gonadotrophin in the obese. Lancet $1954 ; ; 267: 946-7$. [CrossRef]

11. Asher WL, Harper HW. Effect of human chorionic gonadotrophin on weight loss, hunger, and feeling of wellbeing. Am J Clin Nutr 1973; 26:211-8. [CrossRef]

12. Bosch B, Venter I, Stewart RI, Bertram SR. Human chorionic gonadotrophin and weight loss. A double-blind, placebo-controlled trial. S Afr Med J 1990; 77:185-9.

13. Greenway FL, Bray GA. Human chorionic gonadotropin (HCG) in the treatment of obesity: a critical assessment of the Simeons method. West J Med 1977; 127:461-3

14. Stein MR, Julis RE, Peck CC, Hinshaw W, Sawicki JE, Deller JJ Jr. Ineffectiveness of human chorionic gonadotropin in weight reduction: a double-blind study. Am J Clin Nutr 1976; 29:940-8. [CrossRef]

15. Blockeel C, De Vos M, Verpoest W, Stoop D, Haentjens $P$, Devroey P. Can 200 IU of hCG replace recombinant FSH in the late follicular phase in a $\mathrm{GnRH}$-antagonist cycle? A pilot study. Hum Reprod 2009; 24:2910-6. [CrossRef] 